\title{
Acute Bacterial Pneumonia in Rats Increases Alveolar Epithelial Fluid Clearance by a Tumor Necrosis Factor-Alpha-dependent Mechanism
}

\author{
S. Rezaiguia, C. Garat, C. Delclaux, M. Meignan, J. Fleury, P. Legrand, M.A. Matthay, and C. Jayr \\ Department of Anesthesia, Institut National de la Santé et de la Recherche Médicale U 296, Department of Nuclear Medicine, Department \\ of Pathology, and Department of Microbiology, Hôpital Henri Mondor, 94010 Créteil, France; Cardiovascular Research Institute and \\ Department of Anesthesia and Medicine, University of California, San Francisco, California 94143; and Department of Anesthesia, Institut \\ Gustave Roussy, 94805 Villejuif, France
}

\begin{abstract}
To study the rate and regulation of alveolar fluid clearance in acute pneumonia, we created a model of Pseudomonas aeruginosa pneumonia in rats. To measure alveolar liquid and protein clearance, we instilled into the airspaces a 5\% bovine albumin solution with $1.5 \mu \mathrm{Ci}$ of ${ }^{125} \mathrm{I}$-human albumin, $24 \mathrm{~h}$ after intratracheal instillation of bacteria. The concentration of unlabeled and labeled protein in the distal airspaces over $1 \mathrm{~h}$ was used as an index of net alveolar fluid clearance. Since there was histologic evidence of alveolar epithelial injury, several methods were used to measure alveolar fluid clearance, including the use of experiments in rats with blood flow and the use of experiments in rats without blood flow, so that movement across the epithelial barrier would be minimized in the latter group. The results with each method were identical. We found that $P$. aeruginosa pneumonia increased alveolar liquid clearance over $1 \mathrm{~h}$ by $48 \%$ in studies with blood flow, and by $43 \%$ in rats without blood flow, compared with respective controls $(P<$ 0.05). In both studies, this increase was inhibited with amiloride. However, propranolol had no inhibitory effect, thus ruling out a catecholamine-dependent mechanism to explain the increase in alveolar fluid clearance. An antitumor necrosis factor- $\alpha$ neutralizing antibody, instilled into the lung $5 \mathrm{~min}$ before bacteria, prevented the increase in alveolar liquid clearance in rats with pneumonia $(P<0.05)$. Also, TNF $\alpha(5 \mu \mathrm{g})$ instilled in normal rats increased alveolar liquid clearance by $43 \%$ over $1 \mathrm{~h}$ compared with control rats $(P<0.05)$. In normal rats instilled with $\mathrm{TNF} \alpha$, propranolol had no inhibitory effect. In conclusion, gram-negative pneumonia markedly upregulates net alveolar epithelial fluid clearance, in part by a TNF $\alpha$-dependent mechanism. This finding provides a novel mechanism for the upregulation of alveolar epithelial sodium and fluid transport from the distal airspaces of the lung. (J. Clin. Invest. 1997. 99:325-335.) Key words: alveolar epithelium - tumor necrosis factor- $\alpha$ • anti-tumor necrosis factor- $\alpha$ antibody - Pseudomonas aeruginosa $\cdot$ pneumonia
\end{abstract}

Address correspondence to Christian Jayr, Institut Gustave-Roussy, Anesthesie, 39 Rue Camille Desmoulins, 94805 Villejuif Cedex, France. FAX: 33-1-42-11-52-09.

Received for publication 26 March 1996 and accepted in revised form 22 October 1996.

J. Clin. Invest.

(C) The American Society for Clinical Investigation, Inc.

0021-9738/97/01/325/11 \$2.00

Volume 99, Number 2, January 1997, 325-335

\section{Introduction}

Several animal and human studies have established active sodium transport as the primary mechanism driving alveolar liquid clearance in the normal lung (1-3). The alveolar epithelial barrier may play a critical role in regulating alveolar liquid clearance under certain pathological conditions. Septic shock in rats is associated with increased alveolar epithelial fluid clearance (4). Rats exposed to sublethal hyperoxia have increased clearance mediated by stimulated alveolar epithelial sodium uptake $(5,6)$. Also, instillation of endotoxin into the rat lungs results in the upregulation of sodium transport and alveolar liquid clearance at 24 and $40 \mathrm{~h}$ (7).

One of the most frequent causes of nosocomial pneumonia, Pseudomonas aeruginosa, is associated with a high mortality $(8,9)$ and is a common cause of clinical acute lung injury $(10)$. An understanding of the factors that may regulate alveolar epithelial transport in the presence of pneumonia is of major importance. We therefore studied the function of the alveolar epithelial barrier in a model of established $P$. aeruginosa pneumonia in rats.

The first objective of the study was to investigate the hypothesis that the alveolar administration of $P$. aeruginosa organisms would stimulate alveolar epithelial liquid clearance in anesthetized rats. Alveolar fluid clearance was measured by the progressive change in protein concentration of fluid instilled into the airspaces over $1 \mathrm{~h}$, as we have previously described $(3,11,12)$. Adjustments for the loss of alveolar protein were made by measuring residual ${ }^{125} \mathrm{I}$-albumin in the lung, as we have done before (12), and by measuring the dilution of the instilled ${ }^{125} \mathrm{I}$-albumin in the airspaces, a new method developed for this study. Since there was evidence for an increase in alveolar epithelial liquid clearance, the second objective was to study the mechanism by administering amiloride, a sodium transport inhibitor, and propranolol, a beta-adrenergic antagonist, into the distal airspaces of the rats with pneumonia. Although TNF $\alpha$ has been reported to play a role in increased lung epithelial permeability in acute lung injury (13), TNF $\alpha$ has also been reported to increase sodium-dependent amino acid transport in rat hepatocytes (14). Therefore, our third objective was to test the hypothesis that TNFo mediates the bacterially induced increase in alveolar fluid clearance.

\section{Methods}

Pathogen-free male Sprague Dawley rats (mean weight, $370 \mathrm{~g}$ ) were used. The rats were housed in air-filtered, temperature-controlled units with food and water.

\section{Experimental preparation}

Bacterial pneumonia, neutralizing anti-TNF $\alpha$ antibody, and TNF $\alpha$ treatment. Rats were anesthetized by halothane administration via a 
face mask. A median incision was performed in the anterior neck to expose the trachea, and two successive intratracheal instillations using 25-gauge needles were performed. Rats were allocated randomly to receive $0.1 \mathrm{ml}$ either saline or anti-TNF $\alpha$ antibody $(\mathrm{Ab})^{1}$ solution (see below for details), and $\sim 5 \mathrm{~min}$ later, $0.5 \mathrm{ml} / \mathrm{kg}$ either saline or bacterial solution $(P$. aeruginosa). We therefore studied rats with pneumonia ( $P$. aeruginosa), rats with pneumonia pretreated with anti-TNF $\alpha$ antibody ( $P$. aeruginosa $+\mathrm{Ab}$ ), normal rats (saline), and $\mathrm{TNF} \alpha$ antibody-treated rats. Bacterial administration consisted of instillation of a $P$. aeruginosa saline solution $\left(4-8 \times 10^{9} \mathrm{CFU} / \mathrm{ml}\right.$, see below for details). A total of 181 surviving pneumonia and normal rats were studied.

P. aeruginosa inoculum preparation and bacteriology. Preliminary dose-response studies established the inoculum of live $P$. aeruginosa required to induce pneumonia $24 \mathrm{~h}$ after intratracheal instillation. The size of the bacterial inoculum was selected so that the quantitative pulmonary tissue culture would yield $\geq 10^{4} \mathrm{CFU}$ per gram of tissue in all rats with pneumonia at $24 \mathrm{~h}$. A nonmucoid $P$. aeruginosa strain (serotype 11) was used for all studies. These bacteria were maintained in peptone broth containing $25 \%$ glycerol at $-70^{\circ} \mathrm{C}$. Before each experiment, the strain was propagated in tryptone soy agar plates for $24 \mathrm{~h}$ at $37^{\circ} \mathrm{C}$. One colony was then transferred to tryptone soy broth for another $24 \mathrm{~h}$ at $37^{\circ} \mathrm{C}$. On the day of the experiment, the bacteria were centrifuged at $3,000 \mathrm{~g}$ for $15 \mathrm{~min}$ and the pellet of bacteria was washed twice with phosphate buffered saline. $P$. aeruginosa solution was finally resuspended in saline at a concentration of 4-8 $\times$ $10^{9} \mathrm{CFU} / \mathrm{ml}$, and $0.5 \mathrm{ml} / \mathrm{kg}$ of this solution was intratracheally instilled in rats. A sample of bacterial solution was taken for quantitative culture. Samples of blood, pleural lavage liquid, and lung homogenate were obtained aseptically for culture in pneumonia rats $24 \mathrm{~h}$ after the bacterial instillation. The concentration of bacteria was then quantified by placing successive 10 -fold dilutions of the bacterial suspension in tryptone soy agar plates and scoring visible colonies after a 24-h incubation at $37^{\circ} \mathrm{C}$. Regular routine biochemical screening and antibiotic sensitivity testing were done to ensure that the $P$. aeruginosa strain had not changed between experiments.

Neutralizing anti-TNF $\alpha$ antibody. The polyclonal anti-mouse TNF $\alpha$ antibody (Genzyme Corp., Dako, France) used in these studies has been shown to neutralize rat TNF $\alpha$ in vivo (15). To establish the neutralizing dose for these experiments, the antibody was used in several dilutions including 1:10,000, 1:1,000, 1:300, and 1:100; $1: 100$ was sufficient to neutralize $70 \%$ of immonoreactive $\mathrm{TNF} \alpha$ in the lungs (see Fig. 5).

$T N F \alpha$. TNF $\alpha$ (recombinant mouse TNF $\alpha$, Genzyme Corp.) was given intratracheally in normal rats. We used a dose of $5 \mu \mathrm{g}$, previously shown to induce a protective effect against oxygen toxicity in vivo in rats (16).

\section{Specific experimental groups and procedures for these studies}

Alveolar liquid and protein clearance was measured $24 \mathrm{~h}$ after instillation of the bacteria because there was histologic evidence of pneumonia at this time. The effects of amiloride or propranolol, potential inhibitors of alveolar liquid clearance, were studied in rats with pneumonia. To investigate the role of $\mathrm{TNF} \alpha$, experiments were done in pneumonia rats treated with neutralizing anti-TNF $\alpha$ antibody, in normal rats treated acutely either with $\mathrm{TNF} \alpha$ or $\mathrm{TNF} \alpha$ plus propranolol. Normal rats treated with neutralizing anti-TNF $\alpha$ antibody were studied.

The specific protocol for the individual groups for measurement of alveolar liquid clearance (ALC) were: P. aeruginosa group $(n=$ 14), $P$. aeruginosa + Ab group $(n=6)$, control group $(n=10)$, and Ab group $(n=5)$. Additionally, ALC was performed immediately after supplemental instillation of either $(a)$ propranolol ( $P$. aerugi-

1. Abbreviations used in this paper: $\mathrm{Ab}$, anti-TNF $\alpha$ antibody; ALC, alveolar liquid clearance; ARDS, adult respiratory disease syndrome; BAL, bronchoalveolar lavage. nosa + prop, $n=9)$ or amiloride $(P$. aeruginosa + amil, $n=9)$ in rats with pneumonia, or $(b) \mathrm{TNF} \alpha(\mathrm{TNF} \alpha, n=4)$ or $\mathrm{TNF} \alpha$ plus propranolol (TNF $\alpha+$ prop, $n=4)$ in normal rats.

$24 \mathrm{~h}$ after the intratracheal instillations of saline, bacteria, or anti$\mathrm{TNF} \alpha$ antibody, the following previously described procedure was used (11). The rats were anesthetized (intraperitoneal pentobarbital sodium, $50 \mathrm{mg} / \mathrm{kg}$, and pancuronium bromide, $0.5 \mathrm{mg} / \mathrm{kg}$ ) and ventilated supine through an endotracheal tube (tidal volume $=7-8 \mathrm{ml} /$ kg) (rodent ventilator No. 683; Harvard Apparatus, Inc., South Natick, MA) with a $\mathrm{FiO}_{2}$ of 1.0 , a respiratory rate of $60 / \mathrm{min}$ and a positive end expiratory pressure of $3 \mathrm{~cm} \mathrm{H}_{2} \mathrm{O}$. Arterial pressure was continuously monitored through a carotid arterial line. Body temperature was kept constant at $38^{\circ} \mathrm{C}$ with a thermostatically controlled pad. After a 30-min postsurgery baseline of stable heart rate and blood pressure, $1.5 \mu \mathrm{Ci}{ }^{131} \mathrm{I}$-labeled human serum albumin was intravascularly injected. $15 \mathrm{~min}$ later, a $5 \%$ bovine albumin Ringer's lactate solution $(6 \mathrm{ml} / \mathrm{kg})$ with $1.5 \mu \mathrm{Ci}{ }^{125}$ I-labeled human serum albumin was delivered into both lungs over $1 \mathrm{~min}$ via the trachea. In some experiments in pneumonia rats, either amiloride $2 \times 10^{-3} \mathrm{M}$ (Sigma Chemical Co, France) (P. aeruginosa + amil group) or propanolol $10^{-3} \mathrm{M}$ (Sigma Chemical Co.) ( $P$. aeruginosa + prop group) were added to the instilled albumin test solution. In TNF $\alpha$-treated groups, normal rats were intratracheally instilled with the $5 \%$ albumin solution mixed with either $5 \mu \mathrm{g}$ $\mathrm{TNF} \alpha$ (TNF $\alpha$ group), or TNF $\alpha$ plus propranolol $10^{-3} \mathrm{M}(\mathrm{TNF} \alpha+$ prop group). After a 1-h ventilation, a sample of alveolar fluid (0.2$0.3 \mathrm{ml}$ ) was aspirated using a $5-\mathrm{ml}$ syringe and silastic tubing that was passed into a wedged position in both lungs. The lungs were then removed through a mid-line sternotomy. Blood samples were obtained at the beginning and after $1 \mathrm{~h}$. The total protein concentration and the radioactivity of the instillate, blood, and alveolar fluid samples were measured. Radioactivity counts were also measured in the lungs.

\section{Protocol to validate measurement of alveolar liquid clearance}

The details for the methods for calculation of ALC are provided in the measurements section of the Methods. To validate this method in the injured lung, several experimental approaches were used.

First, the instilled $5 \%$ albumin solution with ${ }^{125}$ I-albumin was sampled over $1 \mathrm{~min}$ after instillation into the airspaces of the rats with pneumonia, to measure the change in the concentration of the labeled and the unlabeled protein, and then taking into account the dilution by nonlabeled protein-rich alveolar edema fluid. To be certain that the ${ }^{125} \mathrm{I}$ and ${ }^{131} \mathrm{I}$ labels remained attached to the albumin, and that the albumin was not denatured during the experiment, electrophoresis over a $10-15 \%$ gradient polyacrylamide gel (Phast System; Pharmacia LKB Biotechnology Inc., Piscataway, NJ) was carried out on samples of blood and fluid aspirated from the airspaces $1 \mathrm{~min}$ and 60 min after instillation in rats with pneumonia. In addition, the osmolality of the initial $(312 \pm 5 \operatorname{mosM})$ and final $(312 \pm 23 \operatorname{mosM})$ alveolar fluid samples were measured in four rats.

Second, we eliminated bidirectional protein movement by exsanguinating rats and measuring alveolar fluid clearance over $1 \mathrm{~h}$, as we have done in sheep (17) and in excised human lungs $(2,18)$. In these previous studies $(2,17,18)$, it has been shown that alveolar fluid clearance does not depend on blood flow. Thus, studies without blood flow were conducted in exsanguinated (Exs.) pneumonia rats (Exs. P. aeruginosa group, $n=4$ ), and the effects of propranolol or amiloride were measured (Exs. $P$. aeruginosa + prop group, $n=4$, and Exs. $P$. aeruginosa + amil group, $n=4)$. For controls, normal exsanguinated rats were used. In these studies without blood flow, exsanguination was done before the intratracheal instillation of the albumin solution.

\section{Extravascular lung water}

The effect of live alveolar $P$. aeruginosa and anti-TNF $\alpha$ antibody on extravascular lung water was measured in each group. At the end of the experimental period, the animals were exsanguinated and the lungs were removed and processed for gravimetric determination of extravascular water and dry weight as in our earlier studies $(7,20)$. 


\section{Bronchoalveolar lavage and differential cell count}

The recruitment of inflammatory cells associated with $P$. aeruginosa alone, anti-TNF $\alpha$ antibody alone, or both anti-TNF $\alpha$ antibody and $P$. aeruginosa instillations into the airspaces was examined in 28 rats. Rats were anesthetized, exsanguinated, and the trachea was exposed. Bronchoalveolar lavage (BAL) was carried out by flushing the lungs nine times with $2.5 \mathrm{ml}$ of $37^{\circ} \mathrm{C}$ sterile pyrogen-free physiological saline via the tracheal cannula. The first fraction was removed. The eight other fractions of $2.5 \mathrm{ml}$ were recovered and pooled. The total number of cells was counted using a standard hemocytometer. Cytospin preparations were made using a Shandon 3 cytocentrifuge (Shandon, France). The cells were air-dried and stained by MayGrünwald Giemsa. Differential cell counts on 200 cells were made using standard morphological criteria.

\section{Histologic examination}

Light microscopy and transmission electron microscopy were carried out in infected and normal rats, without the observer's knowledge of the specific experimental protocol. Rats were prepared as in BAL procedure.

Light microscopy. Lungs were processed by inflating with $10 \mathrm{ml}$ Bouin's fixative (in situ fixation), followed by immersion in fixative solution. Two parasagittal sections were made of each lung and processed in the routine manner for paraffin embedding.

Transmission electron microscopy. Lungs were fixed in situ by inflating $10 \mathrm{ml}$ of $2.5 \%$ glutaraldehyde in Cacodylate buffer followed by immersion in fixative. Blocks of tissue were then postfixed in osmium tetraoxide and embedded in epon as usual. Ultrastructure sections were observed under an EM 301 microscope (Philips, Eindhoven, Netherlands).

\section{Protocol for TNF $\alpha$ measurements}

Pulmonary rat $\mathrm{TNF} \alpha$ levels were measured (see Measurements for details) in normal rats instilled with saline and in rats instilled with $P$. aeruginosa, before and at fixed times after the instillation (30 $\mathrm{min}, 1$, $2,4,6,12$, and $24 \mathrm{~h}$ ). TNF $\alpha$ levels were also measured in rats with pneumonia pretreated with different concentrations of anti-TNF $\alpha$ antibody to determine the necessary concentration of antibody to reduce TNF $\alpha$ levels in the lungs. These studies were done $4 \mathrm{~h}$ after the tracheal instillation, corresponding to the peak TNF $\alpha$ level (see Fig. 4). Rats were anesthetized and exsanguinated; the lungs were then removed and stored at $-80^{\circ} \mathrm{C}$ until measurement of TNF $\alpha$.

\section{Measurements}

Hemodynamics, airway pressure, and arterial blood gases. Systemic arterial and airway pressures were monitored continuously with pressure transducers (Baxter Healthcare Corp., Deerfield, IL) recorded with a computer system (Windo Graf Gould, France). Arterial blood gases were measured before and $30 \mathrm{~min}$ after the instillation of the $5 \%$ albumin solution.

Protein concentration and hemoglobin measurement. Protein concentration was measured by the biuret method. Hemoglobin was measured spectrophotometrically (VP 10. 12; Jouan, France) on the blood samples and on the supernatant obtained after centrifugation of lung homogenate $(15,000 \mathrm{~g}$ for $1 \mathrm{~h})$.

$T N F \alpha$ levels measurement. Pulmonary rat $\mathrm{TNF} \alpha$ levels were measured in duplicate in the lung homogenate using an enzymelinked immunoabsorbent assay system that uses a monoclonal antimouse TNF $\alpha$ antibody (Factor-Test-X ${ }^{\mathrm{TM}}$ Mouse TNF $\alpha$ ELISA Kit; Genzyme Corp.). The results were analyzed spectrophotometrically using an MR600 microplate reader (Dynatech Laboratories, Inc., Chantilly, VA) and TNF $\alpha$ levels were expressed as picograms per milliliter. Accurate sample concentrations of TNF $\alpha$ were determined by comparing their respective absorbances with those obtained for the standards plotted on a standard curve. This immunoreactive method has been shown to be accurate for measuring TNF $\alpha$ in rats (19).
Extravascular lung water. Extravascular lung water was determined as it has been described previously $(11,20)$ by calculating the water to dry weight ratio.

Alveolar liquid clearance. ALC (percent loss over $1 \mathrm{~h}$ from alveolar space of the volume of liquid instilled) was measured by the increase in the final unlabeled alveolar protein concentration, compared with the initial instilled alveolar protein concentration as in earlier studies $(3,7,11,20)$. ALC was calculated as ALC $=\left(V_{\mathrm{i}} \times F w_{\mathrm{i}}-\right.$ $\left.V_{\mathrm{f}} \times F w_{\mathrm{f}}\right) /\left(V_{\mathrm{i}} \times F w_{\mathrm{i}}\right) \times 100$.

$F w$ is the water fraction of the initial (i) and the final (f) alveolar fluid. The water fraction is the volume of water per volume of solution measured by the gravimetric method. $V$ is the volume of the initial (i) and the final (f) alveolar fluid. $V_{\mathrm{f}}(\mathrm{ml})$ was estimated as $V_{\mathrm{f}}=$ $\left(V_{\mathrm{i}} \times T P_{\mathrm{i}} \times F r\right) / T P_{\mathrm{f}}$.

$T P$ is the total protein concentration of the initial (i) and final (f) alveolar fluid. $\mathrm{Fr}$ is the fraction of alveolar tracer ( ${ }^{125} \mathrm{I}$-albumin) protein that remains in the lung at the end of the experiment.

The concentration of the alveolar ${ }^{125} \mathrm{I}$-albumin can also be used to estimate alveolar liquid clearance $(11,20)$. The volume of the final alveolar fluid was then estimated as $V_{\mathrm{f}}=\left(V_{\mathrm{i}} \times{ }^{125} \mathrm{cpm}_{\mathrm{i}} \times F r\right){ }^{125} \mathrm{cpm}_{\mathrm{f}}$.

${ }^{125} \mathrm{cpm}$ is the counts per minute per milliliter of initial (i) and final (f) alveolar fluid. We adopted this method in our studies to provide an additional method to calculate alveolar liquid clearance. Because we knew that some edema fluid was present in the alveoli in rats $24 \mathrm{~h}$ after instillation of $P$. aeruginosa (as per the histologic evaluation), we used the dilution of the instilled ${ }^{125}$ I-albumin solution immediately after instillation to calculate alveolar liquid clearance. Therefore, we collected a sample from the distal airspaces $1 \mathrm{~min}$ after instillation of $5 \%$ bovine albumin solution with the $1.5 \mu \mathrm{Ci}$ of ${ }^{125} \mathrm{I}$-albumin in 10 rats. The initial alveolar ${ }^{125} \mathrm{I}$-albumin concentration was diluted $(67 \%$ of the instilled concentration) in pneumonia rats (see results). Therefore, alveolar liquid clearance was calculated by the rise in the ${ }^{125} \mathrm{I}-\mathrm{al}-$ bumin concentration over $1 \mathrm{~h}$, assuming that the initial labeled albumin was $67 \%$ of the instilled concentration. Since there was no change in the total unlabeled protein concentration (probably because protein-rich edema fluid was present in the alveoli), no adjustment was needed to calculate alveolar liquid clearance by the unlabeled protein method (as described above).

Alveolar barrier protein flux. The bidirectional flux of albumin across the alveolar barrier was calculated by measuring $(a)$ the residual ${ }^{125} \mathrm{I}$-albumin (the alveolar protein tracer) in the lung as well as the accumulation of ${ }^{125} \mathrm{I}$-albumin in the plasma, and $(b)$ the clearance of ${ }^{131}$ I-albumin (the vascular protein tracer) into the extravascular spaces of the lung $(3,12,21-23)$. The measurement of the two tracers was made over a 1 -h period $24 \mathrm{~h}$ after the bacterial instillation.

Clearance from the lung of ${ }^{125} \mathrm{I}$-albumin was determined by multiplying the total radioactivity of the ${ }^{125} \mathrm{I}$-albumin in the instillate by the volume that was instilled. The ${ }^{125} \mathrm{I}$-albumin remaining in the lungs was directly measured by counting the radioactivity of the lungs. This value was then divided by the instilled radioactivity and expressed as a percentage of the instilled tracer. Total ${ }^{125} \mathrm{I}$-albumin in blood was measured by the total counts of ${ }^{125} \mathrm{I}$-albumin in the plasma at the end of the experiment multiplied by the plasma volume (see below). The total ${ }^{125} \mathrm{I}$-albumin in the plasma was then divided by the total instilled ${ }^{125} \mathrm{I}$-albumin for determination of the percentage of the ${ }^{125} \mathrm{I}$-albumin instilled in the plasma.

The plasma volume was calculated as volume plasma $=$ body weight in grams $\times(1-$ hematocrit/100 $) \times 0.07$. To be certain of the accuracy of the calculation of plasma volume, the plasma volume was also measured by the dilution of either a label for plasma $\left({ }^{131} \mathrm{I}\right.$-albu$\mathrm{min})$ or a label for erythrocytes $\left({ }^{51} \mathrm{Cr}\right)$ and plasma $\left({ }^{125} \mathrm{I}\right.$-albumin). No difference was found between the methods; therefore, we could use the two measurement methods interchangeably.

The clearance of ${ }^{131} \mathrm{I}$-albumin (the vascular protein tracer) in the extravascular and in the alveolar spaces of the lung was used as an index of endothelial permeability $(22,24)$. To calculate the amount of ${ }^{131}$ I-albumin present in the extravascular spaces of the lung, we deducted the counts of the blood in the lung from the ${ }^{131} \mathrm{I}$-albumin 
Table I. Effect of P. aeruginosa and Anti-TNFa Antibody on Bacterial Counts in the Lung Homogenate, Pleural Lavage Liquid, and the Blood

\begin{tabular}{|c|c|c|c|c|}
\hline \multirow[b]{2}{*}{ Experimental condition } & \multirow[b]{2}{*}{ No. } & \multirow{2}{*}{$\frac{\text { Lung homogenate }}{\text { Quantitative culture }}$} & Pleural liquid & Blood \\
\hline & & & \multicolumn{2}{|c|}{$\overline{\text { Qualitative culture }}$} \\
\hline & & $c f u / g$ & \multicolumn{2}{|c|}{$\%$ of positive } \\
\hline \multicolumn{5}{|l|}{ Surviving rats at $24 \mathrm{~h}$} \\
\hline Control & 2 & 0 & 0 & 0 \\
\hline Control $+\mathrm{Ab}$ & 2 & 0 & 0 & 0 \\
\hline P. aeruginosa & 4 & $2.8 \pm 4.8 \times 10^{5}$ & 50 & 0 \\
\hline P. aeruginosa $+\mathrm{Ab}$ & 4 & $3.0 \pm 4.6 \times 10^{5}$ & 50 & 0 \\
\hline \multicolumn{5}{|c|}{ Spontaneous death within $24 \mathrm{~h}$} \\
\hline P. aeruginosa & 2 & $5.0 \pm 7.0 \times 10^{9 *}$ & 100 & 100 \\
\hline P. aeruginosa $+\mathrm{Ab}$ & 2 & $5.5 \pm 6.0 \times 10^{9 *}$ & 100 & 100 \\
\hline
\end{tabular}

Data as mean \pm SD. $* P<0.05$ compared with surviving rats with pneumonia. 4-8 $\times 10^{9} \mathrm{cfu} / \mathrm{kg}$ weight was instilled.

counts in the entire lung. The clearance of plasma into the extravascular spaces of the lung was estimated by the following equation previously used $(3,12)$ : extravascular plasma equivalents $={ }^{131} \mathrm{cpm}$ lung $\left({ }^{131} \mathrm{cpm} P l_{\mathrm{f}} \times Q_{\mathrm{B}}\right){ }^{131} \mathrm{cpm} P l$, where ${ }^{131} \mathrm{cpm}$ lung is the total counts per minute in lung, ${ }^{131} \mathrm{cpm} P l_{\mathrm{f}}$ is the counts per minute per milliliter of plasma in the final blood sample, ${ }^{131} \mathrm{cpm} P l$ the counts per minute per milliliter plasma averaged over the time of the experiment and $Q_{\mathrm{B}}$ is the blood volume in the lung.

$Q_{\mathrm{B}}=1.039 \times\left(Q_{\mathrm{H}} \times F W_{\mathrm{H}} \times H b_{\mathrm{S}}\right) /\left(F W_{\mathrm{S}} \times H b_{\mathrm{B}}\right)$, where 1.039 is the density of blood, $Q_{\mathrm{H}}$ the weight of lung homogenate, $F W_{\mathrm{H}}$ the water content of lung homogenate, $H b_{\mathrm{S}}$ the hemoglobin concentration of supernatant of lung homogenate, $F W_{\mathrm{S}}$ the water content in supernatant of lung homogenate, and $H b_{\mathrm{B}}$ the hemoglobin concentration of blood.

To express the ${ }^{131} \mathrm{I}$-albumin counts in the airspaces as a ratio to the plasma counts, ${ }^{131}$ I-albumin counts were measured in the final alveolar fluid sample, and ${ }^{131} \mathrm{I}$-albumin plasma counts were averaged over the course of the experiment. This ratio provided an index of equilibration of the vascular protein tracer into the alveolar compartment, as shown in earlier experimental studies of epithelial permeability $(12,25)$.

\section{Statistical analysis}

The data are summarized as mean \pm SD. The paired Student's $t$ test was used to compare hemodynamic and airway pressure data before and after albumin solution instillation. The one way analysis of vari- ance and the Fisher's exact test were used to compare the different groups. We regarded $P<0.05$ as statistically significant $(26,27)$.

\section{Results}

\section{Evidence for experimental pneumonia}

Effect of P. aeruginosa on mortality of rats over $24 \mathrm{~h}$. The mortality of rats with pneumonia was $50 \%$. There was no difference in mortality between rats instilled with $P$. aeruginos $a$ and rats instilled with both $P$. aeruginos $a$ and anti-TNF $\alpha$-antibody. All rats surviving to $24 \mathrm{~h}$ were apathetic and tachypneic, and gross examination confirmed a heterogenous but diffuse $(\sim 80 \%)$, bilateral pneumonia, with lung edema and pathologic lesions in all of the infected rats that were studied.

Bacteriology. Quantitative cultures of the instillate verified that $2-4 \times 10^{9} \mathrm{cfu} P$. aeruginosa $/ \mathrm{kg}$ were instilled. In surviving rats, $10^{4}-10^{6} \mathrm{cfu} P$. aeruginosa were recovered per gram of lung homogenate after $24 \mathrm{~h}$ (Table I). Blood samples were always culture negative, but $50 \%$ of the pleural lavage liquid cultures were positive. There were no significant differences in lung bacterial counts between the rats treated with anti-TNF $\alpha$ antibody vs. those not treated (Table I).

Bacteriological cultures were done at the time of spontaneous death in four rats that had been instilled with $P$. aeruginos $(n=2)$ or $P$. aeruginosa and anti-TNF $\alpha$ antibody $(n=2)$. In these rats, all blood cultures were positive and lung homogenate quantitative cultures were greater than $10^{8} \mathrm{cfu} / \mathrm{g}$ (Table I). Statistical tests were not done on the quantitative cultures because the number of animals was too small, but it was clear that in nonsurviving animals, the number of bacteria was greater than in the surviving rats.

Cell count in BAL. $24 \mathrm{~h}$ after instillation of $P$. aeruginosa, the total number of polymorphonuclear neutrophils and mononuclear cells recovered by BAL was greater $(P<0.05)$ than in the control rats (Table II). The predominant population of cells were neutrophils. The anti-TNF $\alpha$ antibodies in the airspaces did not modify the BAL cell count compared with control rats. Also, inhibition of the early TNF $\alpha$ peak by administering intraalveolar anti-TNF $\alpha$ antibody in $P$. aerugi$n o s a$-instilled rats did not reduce the inflammatory cell influx (Table II).

Histological examination. In animals inoculated with $P$. aeruginosa $(n=5)$ and killed at $24 \mathrm{~h}$, many alveoli were filled with protein, fibrin, neutrophils, and variable quantities of erythrocytes and macrophages (Fig. 1 a). Ultrastructural examination of the lungs $24 \mathrm{~h}$ after $P$. aeruginosa instillation demonstrated that the alveolar epithelium had been denuded

Table II. Effect of P. aeruginosa and Anti-TNF $\alpha$ Antibody Instillation on Influx of Cells into the Airspaces over 4 and $24 h$

\begin{tabular}{|c|c|c|c|c|c|c|c|}
\hline \multirow[b]{2}{*}{ Experimental condition } & \multirow[b]{2}{*}{ No. } & \multicolumn{2}{|c|}{ Total cells } & \multicolumn{2}{|c|}{ Neutrophils } & \multicolumn{2}{|c|}{ Macrophages } \\
\hline & & $4 \mathrm{~h}$ & $24 \mathrm{~h}$ & $4 \mathrm{~h}$ & $24 \mathrm{~h}$ & $4 \mathrm{~h}$ & $24 \mathrm{~h}$ \\
\hline & & \multicolumn{2}{|c|}{$10^{6} / \mathrm{ml}$ of $B A L$} & \multicolumn{4}{|c|}{$\%$ of total number cells } \\
\hline Control & 3 & $2.3 \pm 0.7$ & $2.7 \pm 1.0$ & $0.5 \pm 0.1$ & $1.1 \pm 0.2$ & $1.6 \pm 0.3$ & $2.1 \pm 0.9$ \\
\hline Control $+\mathrm{Ab}$ & 3 & $2.8 \pm 0.9$ & $3.2 \pm 0.5$ & $0.8 \pm 0.5$ & $1.0 \pm 0.4$ & $2.0 \pm 0.8$ & $1.4 \pm 1.0$ \\
\hline$P$. aeruginosa & 5 & $14.5 \pm 8.4^{*}$ & $28.7 \pm 17.4^{*}$ & $87 \pm 5 *$ & $71 \pm 22 *$ & $13 \pm 5^{*}$ & $19 \pm 9 *$ \\
\hline P. aeruginosa $+\mathrm{Ab}$ & 3 & $13.4 \pm 12.5 *$ & $18.4 \pm 14.0^{*}$ & $79 \pm 20 *$ & $70 \pm 28 *$ & $15 \pm 16^{*}$ & $29 \pm 29 *$ \\
\hline
\end{tabular}

Data as mean $\pm \mathrm{SD} .{ }^{*} P<0.05$ compared with control group. 

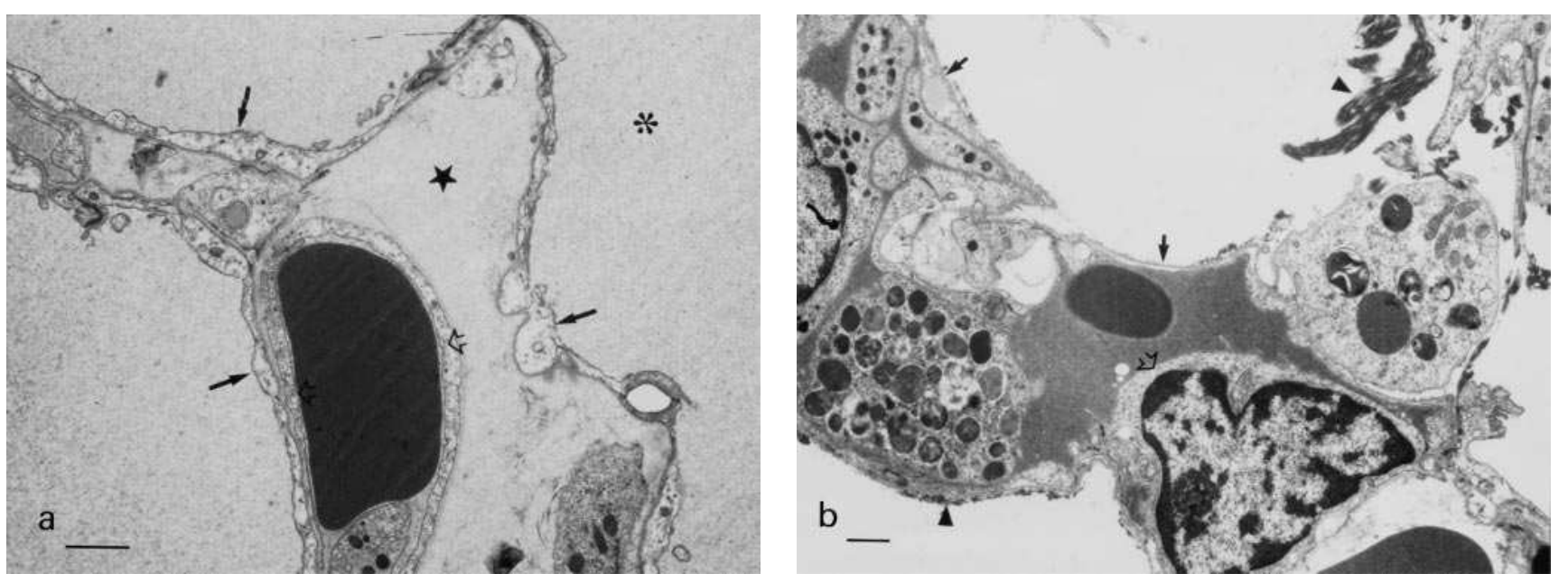

Figure 1. Electron photomicrograph of lung taken $24 \mathrm{~h}$ after instillation of $P$. aeruginos $a$ in rats. $(a)$ The alveoli are filled by edema $(*)$. Note the interstitial edema designated by the swollen connective tissue space $(\star)$. Also, alveolar epithelial cell ultrastructure was generally not affected by $P$. aeruginosa instillation $(\rightarrow)$. The capillary in the center of the micrograph shows intact ultrastructural features of endothelium $(\vec{\imath})$. Magnification 3,371. Horizontal bar $=2 \mu \mathrm{m}$. (b) In contrast, there were focal areas of denuding of the epithelial barrier $(\rightarrow)$ and alveoli filled with fibrin $(\boldsymbol{\Delta})$ as illustrated in this section. The endothelium is also damaged (ㄹ) ). In spite of this evidence of some injury to the epithelial barrier, alveolar liquid clearance was increased, indicating that a significant fraction of the alveolar epithelial barrier was sufficiently intact, with normal tight junctions and a functioning sodium transport system. Magnification 2,457. Horizontal bar $=2 \mu \mathrm{m}$.

in a few areas, providing morphologic evidence of alveolar epithelial barrier injury (Fig. 1 b).

\section{Bidirectional protein flux}

The histological data demonstrated evidence of increased permeability to the endothelial and epithelial barriers with edema fluid in the interstitium and in the airspaces $24 \mathrm{~h}$ after bacterial challenge (Fig. 1). When net protein flux was measured over $1 \mathrm{~h}$ in the rats with pneumonia $24 \mathrm{~h}$ after the instillation of bacteria, the accumulation of the plasma protein tracer ${ }^{131}$ I-albumin in the extravascular and in the airspaces of the lung was higher than in the control group, but did not quite reach statistical significance (Table III). Similarly, the mean flux of the alveolar protein tracer ( ${ }^{125} \mathrm{I}$-albumin) over $1 \mathrm{~h}$ across the alveolar barrier was greater in the $P$. aeruginosa studies (Table III), although the difference did not reach statistical significance, probably because of the short time interval $(1 \mathrm{~h})$ of experiment.

\section{Alveolar liquid clearance in pneumonia}

The initial alveolar protein concentration was not different from the protein concentration of the instilled $5 \%$ albumin solution (initial alveolar/instillate protein concentration ratio $=$ $1.03 \pm 0.02$, as mean $\pm \mathrm{SD}, n=10$ ). In contrast, the concentration of the ${ }^{125} \mathrm{I}$-albumin was significantly decreased in the initial alveolar sample compared with that of the instilled albumin solution (initial alveolar [after $1 \mathrm{~min}$ ]/instillate ${ }^{125} \mathrm{I}$ ratio $=$ $0.67 \pm 0.10$, as mean $\pm \mathrm{SD}, n=10$ ). Thus, this initial dilution of the labeled alveolar albumin tracer was secondary to the dilution by alveolar edema already present in the alveoli (as noted in Fig. 1 a). Because of the evidence for dilution of alveolar tracer to $67 \%$, we assumed that the initial ${ }^{125} \mathrm{I}$-albumin concen-

Table III. Effects of P. aeruginosa, Anti-TNF Antibody and TNF $\alpha$ Treatments on Bidirectional Protein Permeability across the Lung Epithelial Barrier

\begin{tabular}{|c|c|c|c|c|}
\hline \multirow[b]{2}{*}{ Groups } & \multirow[b]{2}{*}{ No. } & \multirow{2}{*}{$\frac{\text { Alveolar protein tracer }}{\text { Recovery of }{ }^{125} \text { I-albumin in the lung }}$} & \multicolumn{2}{|c|}{ Vascular protein tracer } \\
\hline & & & \multicolumn{2}{|c|}{$\begin{array}{l}{ }^{131} \text { I-albumin:extravascular plasma equivalents } \\
\text { in the lung }\end{array}$} \\
\hline & & $\%$ of instilled & $m l$ & $m l$ \\
\hline Control & 6 & $97 \pm 1$ & $0.10 \pm 0.04$ & $0.04 \pm 0.03$ \\
\hline Control $+\mathrm{Ab}$ & 4 & $96 \pm 1$ & $0.08 \pm 0.02$ & $0.03 \pm 0.02$ \\
\hline$P$. aeruginosa & 10 & $94 \pm 5$ & $0.12 \pm 0.04$ & $0.11 \pm 0.06$ \\
\hline P. aeruginosa $+\mathrm{Ab}$ & 6 & $92 \pm 3$ & $0.15 \pm 0.08$ & $0.12 \pm 0.06$ \\
\hline $\mathrm{TNF} \alpha$ & 4 & $98 \pm 1$ & $0.08 \pm 0.04$ & $0.06 \pm 0.04$ \\
\hline $\mathrm{TNF} \alpha+$ prop & 4 & $97 \pm 2$ & $0.09 \pm 0.05$ & $0.05 \pm 0.03$ \\
\hline
\end{tabular}

Data as mean \pm SD. Extravascular plasma equivalents in the lung $={ }^{131} \mathrm{I}$-albumin in lung $-\left({ }^{131} \mathrm{I}\right.$-albumin in final blood sample $\times Q_{\mathrm{B}} /{ }^{131} \mathrm{I}$-albumin in plasma averaged over the 1-h experiment. $Q_{\mathrm{B}}$, blood volume in the lung (see Measurements in Methods). Extravascular plasma equivalents in the alveoli $={ }^{131} \mathrm{I}$-albumin in final alveolar fluid $/{ }^{131} \mathrm{I}$-albumin in plasma averaged over the 1 -h experiment. 


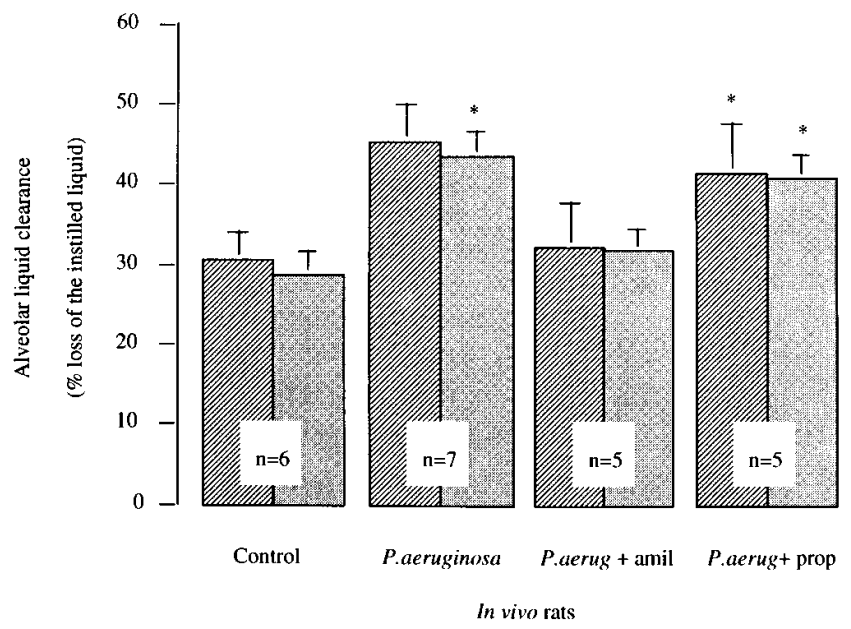

Figure 2. Data (mean \pm SD) on alveolar liquid clearance $24 \mathrm{~h}$ after instillation of $P$. aeruginosa $\left(2-4 \times 10^{9} / \mathrm{kg}\right)$ into the lungs. Alveolar liquid clearance was measured by the increase of the alveolar nonlabeled, $(\square)$, and labeled, $(\square)$, protein concentration. P. aeruginosainstilled rats had significantly increased alveolar liquid clearance ( ${ }^{*} P<0.05$ compared with control and amiloride groups.) This effect was inhibited with amiloride (amil), but not with propranolol (prop).

tration was also $67 \%$ of the instilled concentration and used ${ }^{125}$ I-albumin concentration to estimate alveolar liquid clearance in these studies to provide another method for calculating alveolar liquid clearance besides the concentration of the instilled unlabeled protein.

Alveolar liquid clearance as measured by the increase in concentration of unlabeled protein, which was significantly increased in $P$. aeruginosa-instilled rats by $48 \%$ compared with controls (Fig. 2). Alveolar liquid clearance as measured by the increase of labeled alveolar protein tracer concentration was similarly increased by $50 \%$ in $P$. aeruginosa-instilled rats (Fig. 2).

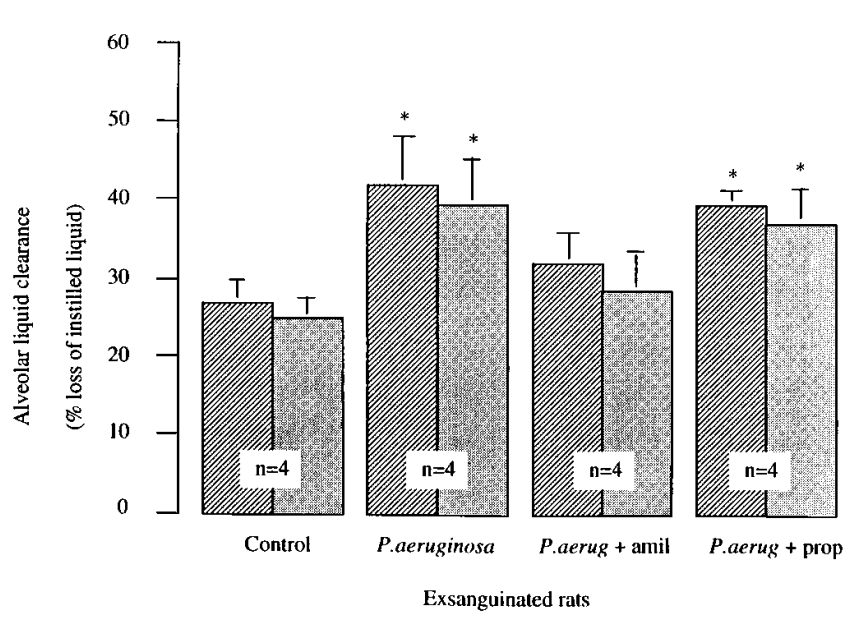

Figure 3. Data (mean \pm SD) on alveolar liquid clearance in exsanguinated rats. Alveolar liquid clearance was measured by the increase of the alveolar nonlabeled, $(\square)$, and labeled, $(\square)$, protein concentration. Experiments were done with control and after $P$. aeruginosa instillation into the lungs. In exsanguated rats, as in Fig. 2, amiloride (amil) inhibited the increased alveolar liquid clearance, but propranolol (prop) did not. $* P<0.05$ compared with the control, exsanguinated group.

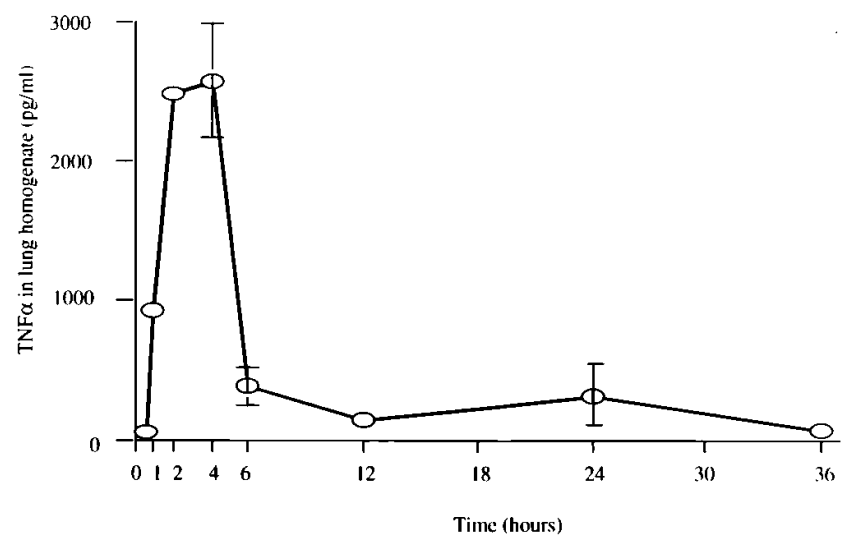

Figure 4. TNF $\alpha$ levels in the lung homogenates after instillation of $P$. aeruginosa into the lungs. Data are shown for several time points $(n=$ 4 at 4,6 , and $24 \mathrm{~h}, n=1$ at other times).

Experiments without blood flow. In exsanguinated rats, the experiments corroborated data provided by the in vivo studies. With both labeled and unlabeled alveolar protein, a similar increase in alveolar liquid clearance occurred in the rats with pneumonia (Fig. 3).

\section{Effect of amiloride and propranolol on alveolar liquid} clearance in pneumonia

In both experiments with and without blood flow in pneumonia rats, amiloride resulted in a return of alveolar liquid clearance to basal levels; amiloride prevented the major part of the increase in alveolar liquid clearance (Figs. 2 and 3). In contrast, propranolol had no effect on the stimulated clearance (Figs. 2 and 3).

Also, measurements of alveolar liquid clearance using the increase of ${ }^{125} \mathrm{I}$-albumin concentration, based on the assump-
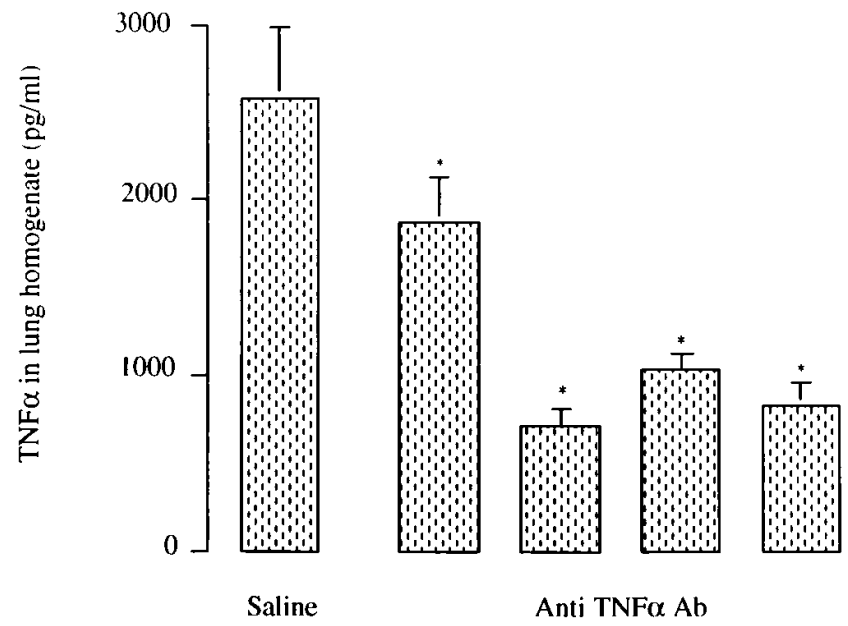

Anti TNF $\alpha \mathrm{Ab}$

$1 / 10,000 \quad 1 / 1,000 \quad 1 / 300$

$1 / 100$

Figure 5. Effect of anti-TNF $\alpha$ antibody treatment on TNF $\alpha$ levels in the lung homogenates $4 \mathrm{~h}$ after $P$. aeruginos $a$ instillation into the lungs. The anti-TNF $\alpha$ serum was diluted in saline at concentrations: $1 / 10,000,1 / 1,000,1 / 300$, and $1 / 100$ before it was instilled into the airspaces of the lung. Data are listed as mean \pm SD. $* P<0.05$ compared with saline instillation. 


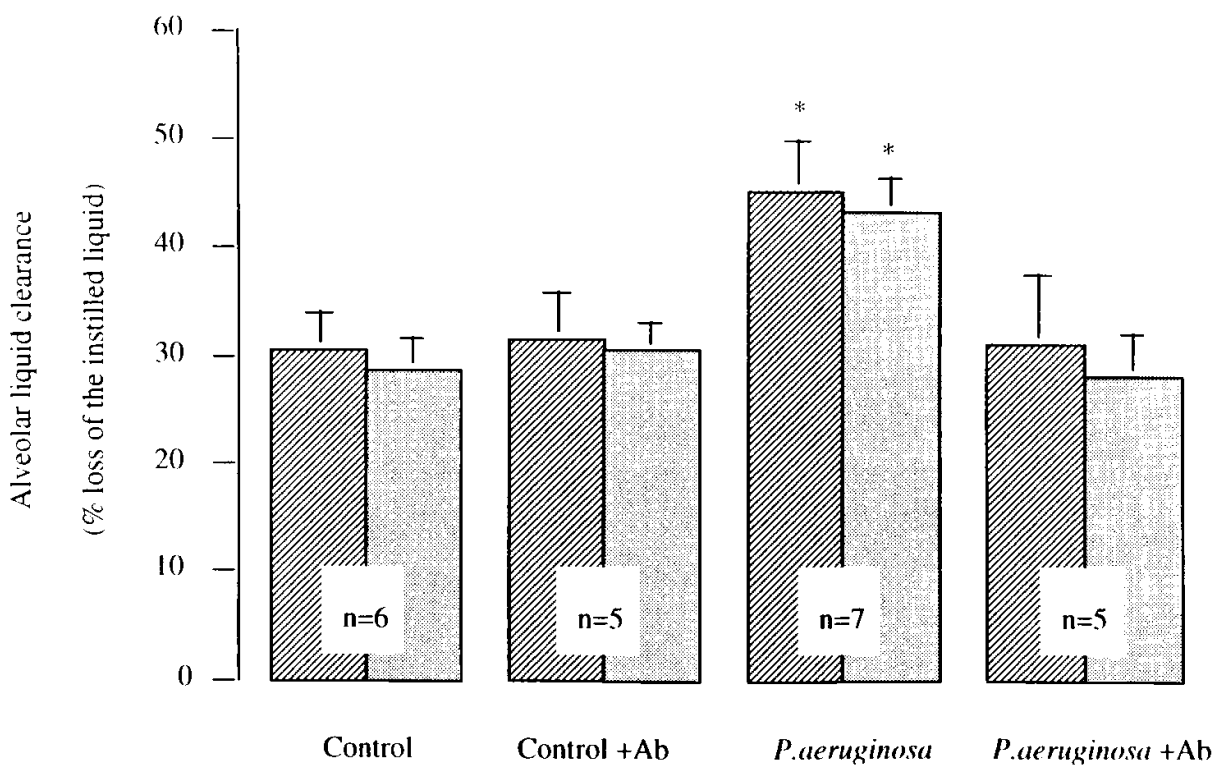

In vivo rats
Figure 6. Data (mean $\pm \mathrm{SD})$ on alveolar liquid clearance in control, $P$. aeruginosa, anti-TNF $\alpha$ antibody alone, and $P$. aeruginosa + anti-TNF $\alpha$ antibody instilled. Alveolar liquid clearance was measured by the increase of the alveolar nonlabeled, $(\square)$, and labeled, $(\square)$, protein concentration. The anti-TNF $\alpha$ antibody prevented the $P$. aeruginosastimulated increase in alveolar liquid clearance. $* P<0.05$ compared with control group. tion that the initial ${ }^{125}$ I-albumin concentration was $67 \%$ of the instilled concentration, were consistent with alveolar liquid clearance calculated from the increase of nonlabeled protein concentration (Figs. 2 and 3 ).

\section{Effect of anti-TNF $\alpha$ antibody on alveolar fluid clearance}

$T N F \alpha$ levels in lung homogenate tissue. High levels of lung homogenate TNF $\alpha$ were measured with a peak at $4 \mathrm{~h}$ in rats with pneumonia (Fig. 4). Because of this early peak of TNF $\alpha$, neutralizing anti-TNF $\alpha$ antibody was instilled just before $P$. aeruginosa inoculum. With this protocol, rats that were in-

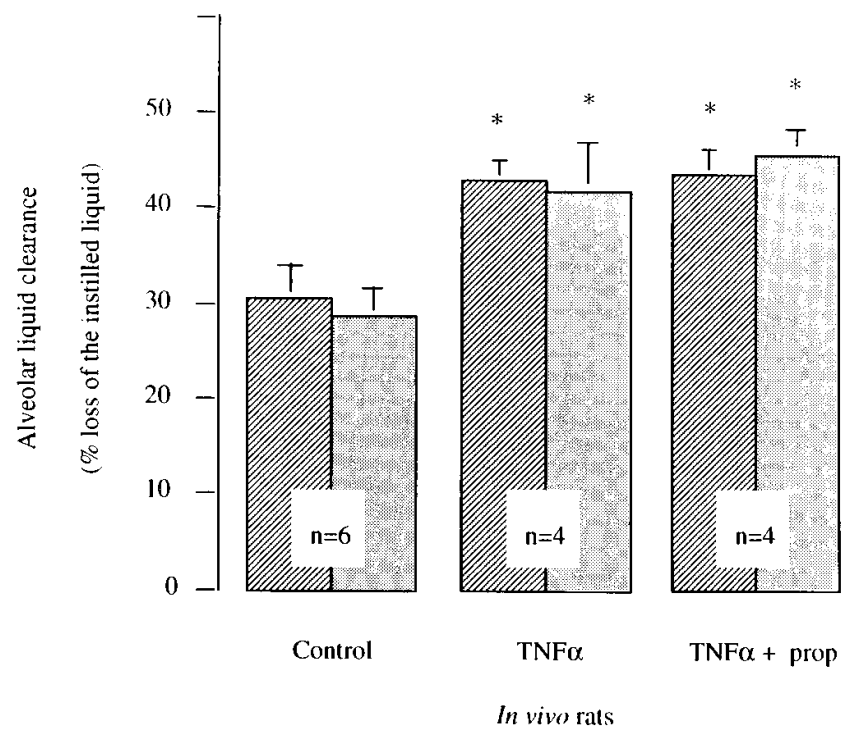

Figure 7. Data (mean \pm SD) on alveolar liquid clearance in control, $\mathrm{TNF} \alpha$ alone, and $\mathrm{TNF} \alpha+$ propranolol-instilled rats. Alveolar liquid clearance was measured by the increase of the alveolar nonlabeled, $(\square)$, and labeled, $(\square)$, protein concentration. Administration of TNF $\alpha(5 \mu \mathrm{g})$ stimulated alveolar liquid clearance by $43 \%$. This effect was not inhibited by propanolol (prop). $* P<0.05$ compared with control group. stilled with both $P$. aeruginos $a$ and neutralizing anti-TNF $\alpha$ antibody had a dose-dependent decrease in TNF $\alpha$ levels (Fig. 5).

Anti-TNF $\alpha$ antibody instilled alone $24 \mathrm{~h}$ before the experiment did not modify alveolar liquid clearance in $\mathrm{Ab}$ group (Fig. 6). However, in rats with pneumonia, the stimulated fraction of the alveolar liquid clearance, estimated with labeled or nonlabeled protein, was almost completely inhibited when an anti-TNF $\alpha$ antibody treatment was given (Fig. 6).

\section{Effect of TNF $\alpha$ instillation into the airspaces on alveolar} fluid clearance

$\mathrm{TNF} \alpha(5 \mu \mathrm{g})$ was instilled with the albumin test solution at the beginning of the experiment in normal rats. TNF $\alpha$ significantly

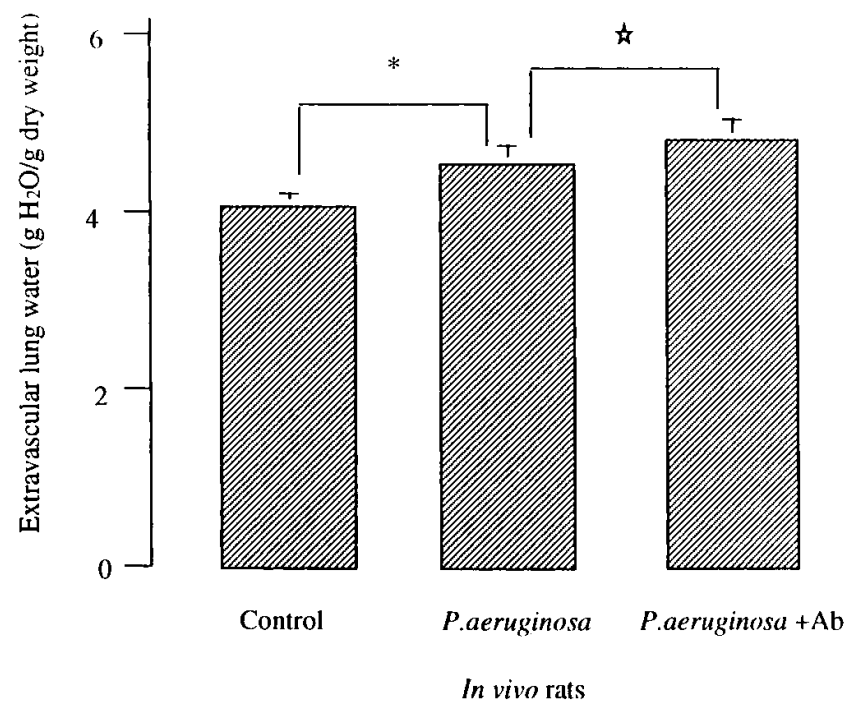

Figure 8. Effect of P. aeruginosa and P. aeruginosa + anti-TNF $\alpha$ antibody on the water to dry weight ratio after $24 \mathrm{~h}$. Data as mean \pm SD. $* P<0.05$ compared with control group. के $P<0.05$ compared with $P$. aeruginosa. The anti-TNF $\alpha$ antibody treatment in pneumonia rats is associated with an increased water to dry weight ratio. 
Table IV. Effect of P. aeruginosa and Anti-TNF $\alpha$ Antibody Instillation on Baseline $\mathrm{PaO}_{2} / \mathrm{FiO}_{2}$ and Mean Systemic Arterial Pressure after $24 \mathrm{~h}$

\begin{tabular}{lrlc}
\hline \multicolumn{1}{c}{ Groups } & No. & $\mathrm{PaO}_{2} / \mathrm{FiO}_{2}$ & $\begin{array}{c}\text { Mean systemic } \\
\text { arterial pressure }\end{array}$ \\
& & \multicolumn{2}{c}{$m m H g$} \\
Control & 6 & $490 \pm 45$ & $131 \pm 10$ \\
Control $+\mathrm{Ab}$ & 5 & $448 \pm 40$ & $125 \pm 7$ \\
$P$. aeruginosa & 10 & $170 \pm 132^{*}$ & $110 \pm 34$ \\
$P$. aeruginosa $+\mathrm{Ab}$ & 6 & $127 \pm 101^{*}$ & $102 \pm 38$ \\
& & & \\
\hline
\end{tabular}

Data as mean \pm SD. $* P<0.05$ compared with control groups. Difference between the two groups with pneumonia did not reach a statistical significance.

increased alveolar liquid clearance by $43 \%$, as measured with labeled or non labeled protein (Fig. 7). As in rats with pneumonia experiments (Figs. 2 and 3), propranolol did not reduce the stimulatory effect of acute $\mathrm{TNF} \alpha$ treatment on alveolar liquid clearance (Fig. 7).

\section{Extravascular lung water}

Extravascular lung water was increased by $12 \%(P<0.05)$ in rats with pneumonia compared with controls (Fig. 8). Also, rats with pneumonia treated with the anti-TNF $\alpha$ antibody had an even higher extravascular lung water than the untreated pneumonia rats (Fig. 8).

\section{Airway pressure, body temperature, mean arterial pressure} and oxygenation

Peak airway pressure and rectal temperature $24 \mathrm{~h}$ immediately after $P$. aeruginosa instillation were similar in all groups. No difference was found in systemic arterial pressure between the groups (Table IV). Oxygenation was significantly lower in the rats with pneumonia, with a major decrease in the $\mathrm{PaO}_{2}$ (Table IV). In the anti-TNF $\alpha$ antibody-treated pneumonia rats, the mean $\mathrm{PaO}_{2} / \mathrm{FiO}_{2}$ ratio was $25 \%$ lower than in the untreated rats with pneumonia (Table IV), although this difference did not quite reach statistical significance.

\section{Discussion}

Since alveolar epithelial barrier fluid transport is critical for the resolution of edema in patients with acute lung injury (1), we studied alveolar fluid clearance in a rat model of severe acute lung injury from pneumonia. Until recently, there had been few data available regarding the regulation of alveolar barrier function under experimental conditions that simulate acute lung injury in patients with adult respiratory distress syndrome (ARDS). One recent report indicated upregulation of alveolar epithelial sodium and fluid transport after hyperoxic exposure in rats (28), and we have reported catecholamine upregulation in septic shock (20). This experimental study was focused on the function of the alveolar epithelium after the development of gram-negative pneumonia in rats, $24 \mathrm{~h}$ after the instillation of $P$. aeruginosa. In spite of histological evidence of some injury to the epithelial barrier, net alveolar liquid clearance was stimulated, a finding that is consistent with studies demonstrating the ability of the alveolar epithelial barrier to remove fluid in the presence of injury $(1,29)$. Therefore, we in- vestigated the mechanisms that accounted for the increased alveolar liquid clearance in this in vivo model of gram-negative pneumonia.

Exposure to $P$. aeruginosa for $24 \mathrm{~h}$ induces pneumonia, based on bacteriologic criteria (Table I), physiologic criteria (hypoxemia) (Table IV), histologic evidence (Fig. 1), and a $50 \%$ spontaneous mortality rate. The presence of acute pneumonia was also demonstrated by a significant increase in the water to dry ratio of infected rats compared with those of control rats (Fig. 8). The lung injury in this acute bacterial model is characterized by an early influx of neutrophils and monocytes into the bronchoalveolar lavage fluid (Table II). All infected rats studied had a diffuse pneumonia as supported by gross examination of the lungs, associated with severe hypoxemia: $60 \%$ of the infected rats had a $\mathrm{PaO}_{2} / \mathrm{FiO}_{2}$ ratio $<200 \mathrm{mmHg}$, which is one criteria of ARDS (30).

To study the capacity of the alveolar epithelial barrier to remove fluid, we instilled a protein solution into the distal airspaces of the lung $24 \mathrm{~h}$ after the instillation of $P$. aeruginosa. There was a net increase in alveolar fluid clearance of $48 \%$ in the rats with pneumonia compared with control rats (Fig. 2). How can we be sure that this calculation of alveolar fluid clearance is accurate?

The purpose of these studies is to examine net alveolar epithelial fluid clearance. This model of pneumonia faithfully reproduces the clinical problem, which is diffuse but does not necessarily involve all alveoli. A recent study demonstrated that local $P$. aeruginosa instillation (approximately similar to the high dose used in our studies) induces contralateral lung injury (31).

Since there was histologic and gravimetric evidence of injury to the endothelial and epithelial barrier of the lung, several experimental approaches were used to evaluate carefully our method of alveolar fluid clearance measurement.

Calculation of alveolar liquid clearance required measurement of total protein concentration in the albumin test solution and in the alveolar fluid sampled by a catheter $1 \mathrm{~h}$ after instillation of the isosmolar albumin test solution. The concentrations of the native protein in the liquid sampled by a catheter wedged into the distal airways and obtained by alveolar micropuncture are the same (23). Also, the instilled 5\% albumin solution with ${ }^{125}$ I-albumin was sampled over $1 \mathrm{~min}$ after instillation into the airspaces of 10 rats with pneumonia; no change in the total protein concentration was found because proteinrich edema fluid was already present in the alveoli. Therefore, we could use the total protein concentration measured in the albumin test solution as the initial alveolar protein concentration, and the total protein concentration measured in the fluid sampled from the airspaces as the final alveolar protein concentration in the equation for ALC calculation. Also, short time experiments were conducted $(1 \mathrm{~h})$ so the bidirectional protein movements were minimized in injured lungs, and two methods were used to measure the bidirectional protein flux across the alveolar epithelial barrier. The first method required measurement of the residual ${ }^{125}$ I-albumin (the alveolar protein tracer) in the lung as well as the accumulation of the ${ }^{125} \mathrm{I}$-albumin in the plasma. The latter method required measurement of ${ }^{131} \mathrm{I}$-albumin (the vascular protein tracer) in the air space compartment of the lung. Thus, by using both a vascular and an alveolar protein tracer, the magnitude of the bidirectional protein flux after lung injury can be evaluated. In these conditions, because there was not a marked change in epithe- 
lial permeability after $1 \mathrm{~h}$ of experiment in rats instilled with $P$. aeruginosa, the alveolar volume can be estimated by comparing the final with the initial protein concentration to calculate the alveolar liquid clearance, confirming the validity of the measurement of alveolar liquid clearance using nonlabeled protein.

In the alveolar space, as expected, ${ }^{125}$ I-albumin concentration was significantly decreased in the alveolar sample obtained 1 min after instillation compared with that of the instilled albumin solution (initial alveolar/instillate ${ }^{125} \mathrm{I}$ ratio $=$ $0.67 \pm 0.10$ ), because the protein tracer was diluted by nonlabeled protein-rich alveolar edema fluid. Therefore, we also calculated alveolar liquid clearance using the increase in ${ }^{125} \mathrm{I}$ albumin concentration over $1 \mathrm{~h}$, taking into account the dilution of the labeled alveolar albumin (estimated initial ${ }^{125} \mathrm{I}$-albu$\left.\min =\mathrm{cpm}_{\mathrm{i}} \times 0.67\right)$. The alveolar liquid clearance calculations were almost identical using the labeled and unlabeled albumin concentration over $1 \mathrm{~h}$ (Figs. 2 and 3). Since we measured a net increase in fluid movement across the alveolar epithelial barrier, the epithelium must have been sufficiently intact to remove excess alveolar fluid.

To use a third method to confirm our calculations, we eliminated bidirectional protein movement by exsanguinating rats and measuring alveolar fluid clearance over $1 \mathrm{~h}$ as we have done in sheep (17) and in excised human lungs (2). A comparable increase in alveolar liquid clearance was found in these experiments with and without blood flow (Figs. 2 and 3). This finding further validated the results of previous in vivo studies that had demonstrated that the process of alveolar fluid reabsorption does not depend on the blood flow in short term studies $(2,32)$.

The addition of amiloride to the instilled protein solution, in experiments both with (Fig. 2) and without (Fig. 3) blood flow, resulted in a return of alveolar liquid clearance to basal levels. In our previous studies, we reported that amiloride inhibited $44 \%$ of alveolar liquid clearance in control rats $(7,11)$. The dose of $2 \times 10^{-3} \mathrm{M}$ amiloride was used because $50 \%$ of amiloride is bound to protein (33) and a significant fraction escaped from the airspaces (34). The increased clearance in rats with pneumonia depended on a stimulatory uptake of sodium across the alveolar epithelium. This effect could be attributed either to a recruitment of new channels, or to an increase in the open-time probability of existing channels (6). The possibilty that other amiloride-sensitive $\mathrm{Na}^{+}$channels, such as $\mathrm{Na}^{+}-\mathrm{H}^{+}$antiporter or $\mathrm{Na}^{+}-\mathrm{Ca}^{2+}$, contribute to the stimulatory effect in vivo cannot be excluded (35).

After we determined that the stimulated liquid clearance from the distal airspaces in infected rats was dependent on an increase in sodium-dependent uptake by lung epithelial cells, we explored the potential influence of adrenergic mechanisms on clearance (20). Several studies have reported dense betareceptor binding in the alveolar walls in different species, including rats and humans (36-39). Also, exogenous administration of beta-adrenergic agonists stimulates active sodium transport across the epithelial barrier of the lung in in vivo models $(3,11)$, in perfused rat lungs $(40,41)$, and in in vitro models $(42,43)$. Additionally, septic shock in rats accelerates alveolar epithelial liquid clearance by release of endogenous epinephrine (20). In this study, the increase in alveolar liquid clearance in rats with pneumonia both with (Fig. 2) and without (Fig. 3) blood flow was comparable with the increase reported in beta-adrenergic therapy $(3,11)$. However, propran- olol, a beta-adrenergic antagonist, did not reduce this effect. Therefore, the upregulation of net alveolar fluid clearance was not mediated by stimulation of epithelial beta-receptors in this 24-h model of bacterial pneumonia. One explanation could be that the release of endogenous catecholamines occurs early and return to normal levels in pneumonia. It has been shown that rats treated with intravenous endotoxin have an immediate rise in plasma epinephrine, but a decrease over time so that plasma epinephrine concentrations after $6 \mathrm{~h}$ are $<20 \%$ of the initial value (44). Thus, while endogenous release of catecholamines may either protect against alveolar edema or hasten its resolution in some pathological conditions, this mechanism did not account for the stimulated clearance in these 24-h studies of rats with pneumonia.

The probable role of $\mathrm{TNF} \alpha$ in endotoxic challenge in human subjects (45) and in patients with septic-induced ARDS $(46,47)$ has been well studied. Some experimental studies implicate $\mathrm{TNF} \alpha$ in the increase of lung endothelial or epithelial permeability $(13,48)$. However, it is also known that TNF $\alpha$ can increase sodium-dependent amino acid transport in rat hepatocytes (14). Therefore, our third objective was to test the hypothesis that $\mathrm{TNF} \alpha$ could mediate the increase in alveolar fluid clearance in this 24 -h model of severe bacterial pneumonia. We eliminated $70 \%$ of the rise in $\mathrm{TNF} \alpha$ detected in the lung by instilling the anti-TNF $\alpha$ antibody before $P$. aeruginosa. In rats with pneumonia that were pretreated with anti$\mathrm{TNF} \alpha$ antibody, alveolar liquid clearance was comparable to those measured in control rats (Fig. 6). In addition, instillation of $\mathrm{TNF} \alpha$ in normal rats increased alveolar liquid clearance by $43 \%$ compared with controls (Fig. 7). These results indicate that the in vivo administration of live $P$. aeruginosa into the distal airspaces results in an increase of the alveolar epithelial sodium uptake, which can be upregulated by a TNF $\alpha$-dependent mechanism. The stimulated alveolar liquid clearance with acute $\mathrm{TNF} \alpha$ treatment and $P$. aeruginosa pneumonia were not reduced by propranolol (Fig. 7), indicating that this effect is not mediated by an adrenergic mechanism.

The results are internally consistent. For example, separate indices suggested that anti-TNF $\alpha$ antibody pretreatment of infected rats resulted in a worsening of lung injury. Pretreated rats with pneumonia had more pulmonary edema (Fig. 8) and a tendency toward worse oxygenation (Table IV) compared with infected rats without pretreatment. Interestingly, the BAL cell counts of the two groups were the same (Table II). Tang et al. (49) have reported recently that a tracheal insufflation of LPS or IL-1 with anti-TNF $\alpha$ antibody at concentrations that completely neutralized LPS or IL-1-induced activity has no effect on the LPS or IL-1-induced changes in the numbers of BAL total white blood cells, macrophages, or neutrophils.

Cytokines are endogenous proteins that play a crucial role in host defenses against infection. Yet, when proinflammatory cytokines are produced in excess, they can trigger a cascade of deleterious events resulting in shock and multiple organ failure. While TNF $\alpha$ has been one of the proximal cytokines implicated in the pathophysiology of septic shock, very different effects were observed with anti-TNF $\alpha$ antibody in experimental infectious models. In mice, anti-TNF $\alpha$ antibody had a protective effect against endotoxin (50). On the contrary, in rats with streptocoque B sepsis, the mortality was the same between untreated and treated anti-TNF $\alpha$ antibody groups (15).

What is the possible cellular basis for the TNF $\alpha$ effect in 
these studies? There are two distinct TNF receptors that are expressed in a wide variety of tissues, including A549 cells (a cell line with features of alveolar type II cells) (51, 52). After binding to the receptor, TNF $\alpha$ may induce a variety of intracellular signals. Since TNF $\alpha$ is known to decrease cAMP (53, 54 ), it is not likely that the enhanced sodium and fluid absorption in these studies is mediated by cAMP, a second messenger that is known to increase vectorial sodium transport in alveolar type II cells $(35,40)$. However, interestingly, TNF $\alpha$ does regulate $\mathrm{G}$ proteins (55), and recently $\mathrm{G}$ proteins have been reported to regulate amiloride-sensitive sodium uptake in fetal alveolar type II epithelial cells (56). There is also recent evidence that TNF- $\alpha$ can increase uptake of sodium into cells by inserting an ion channel into cell membranes (57).

In summary, acute $P$. aeruginosa pneumonia in rats results in a marked upregulation of the rate of net alveolar epithelial sodium and fluid clearance. The upregulation of alveolar fluid clearance depends in part on a TNF $\alpha$ stimulation of alveolar epithelial sodium uptake, a novel mechanism that may have important clinical implications.

\section{Acknowledgments}

The authors thank Dr. Kouyoumdjian, Brigitte Boissier, and Liliane Leclerc for their technical assistance in carrying out these studies and Anton Ford for reviewing the manuscript.

This study was supported by Association pour la Recherche sur le Cancer grant ARC-6908 and by a National Institutes of Health grant (HL-51854) to M.A. Matthay.

\section{References}

1. Matthay, M.A., and J.P. Wiener-Kronish. 1990. Intact epithelial barrier function is critical for the resolution of alveolar edema in humans. Am. Rev. Respir. Dis. 142:1250-1257.

2. Sakuma, T., G. Okaniwa, T. Nakada, T. Nishimura, S. Fujimura, and M.A. Matthay. 1994. Alveolar fluid clearance in the resected human lung. Am. J. Respir. Crit. Care Med. 150:305-310.

3. Berthiaume, Y., N.C. Staub, and M.A. Matthay. 1987. Beta-adrenergic agonists increase lung liquid clearance in anesthetized sheep. J. Clin. Invest. 79: 335-343.

4. Olivera, W.G., K. Ridge, L.D.H. Wood, and J.I. Sznajder. 1993. Atrial natriuretic factor decreases active sodium transport and increases alveolar epithelial permeability. J. Appl. Physiol. 75:1581-1586.

5. Sznajder, J.I., W.G. Olivera, K.M. Ridge, and D.H. Rutschman. 1995. Mechanisms of lung liquid clearance during hyperoxia in isolated rat lungs. Am. J. Respir. Crit. Care Med. 151:1519-1525.

6. Haskell, J.F., G. Yue, D.J. Benos, and S. Matalon. 1994. Upregulation of sodium conductive pathways in alveolar type II cells in sublethal hyperoxia. Am. J. Physiol. 66:L30-L37.

7. Garat, C., S. Rezaiguia, M. Meignan, M.P. d'Ortho, A. Harf, M.A. Matthay, and C. Jayr. 1995. Alveolar endotoxin increases liquid clearance in rats. $J$. Appl. Physiol. 79:2021-2028.

8. Bryan, C.S., and K.L. Reynolds. 1984. Bacterial nosocomial pneumonia analysis of 172 episodes from a single metropolitan area. Am. Rev. Respir. Dis. 129:668-671.

9. Collins, C.D., C.S. Darke, and J. Knoweleden. 1986. Chest complications after upper abdominal surgery, their anticipation and prevention. $\mathrm{Br}$. Med.J. 1: 401-406.

10. Doyle, R.L., N. Szaflarski, G.W. Modin, J.P. Wiener-Kronish, and M.A. Matthay. Identification of patient with acute lung injury. Predictors of mortality. Am. J. Respir. Crit. Care Med. 152:1818-1824.

11. Jayr, C., C. Garat, M. Meignan, J.F. Pittet, M. Zelter, and M.A. Matthay. 1994. Alveolar liquid and protein clearance in anesthetized, ventilated rats. J. Appl. Physiol. 76:2636-2642.

12. Wiener-Kronish, J.P., K.H. Albertine, and M.A. Matthay. 1991. Differential responses of the endothelial and epithelial barriers of the lung in sheep to Escherichia coli endotoxin. J. Clin. Invest. 88:864-875.

13. Li, X.Y., K. Donaldson, D. Brown, and W. MacNee. 1995. The role of tumor necrosis factor in increased airspace epithelial permeability in acute lung inflammation. Am. J. Respir. Cell Mol. Biol. 13:185-195.

14. Pacitti, A.J., Y. Inoue, and W.W. Souba. 1993. Tumor necrosis factor stimulates amino acid transport in plasma membrane vesicles from rat liver. $J$. Clin. Invest. 91:474-483.

15. Teti, G., G. Mancuso, and F. Tomasello. 1993. Cytokine appearance and effects of anti-tumor necrosis factor alpha antibodies in a neonatal rat model of group B streptococcal infection. Infect. Immun. 61:227-235.

16. Tsan, M., J.E. White, T.A. Santana, and C.Y. Lee. 1990. Tracheal insufflation of tumor necrosis factor protects rats against oxygen toxicity. J. Appl. Physiol. 68:1211-1219.

17. Sakuma, T., J.F. Pittet, C. Jayr, and M.A. Matthay. 1993. Alveolar liquid and protein clearance in the absence of blood flow or ventilation in sheep. $J$. Appl. Physiol. 74:176-185.

18. Sakuma, T., S. Suzuki, K. Usuda, M. Handa, G. Okaniwa, T. Nakada, S. Fujimura, and M.A. Matthay. 1996. Preservation of alveolar epithelial fluid transport mechanisms in rewarmed human lung after severe hypothermia. $J$. Appl. Physiol. 80:1681-1686.

19. Pizarro, T.T., K. Malinowska, E.J. Kovacs, J. Clancy, Jr., J.A. Robinson, and L.A. Piccinini. 1993. Induction of TNF alpha and TNF beta gene expression in rat cardiac transplants during allograft rejection. Transplantation (Baltimore). 36:399-404.

20. Pittet, J.F., J.P. Wiener-Kronish, M.C. McElroy, H.G. Folkesson, and M.A. Matthay. 1994. Stimulation of lung epithelial liquid clearance by endogenous release of catecholamines in septic shock in anesthetized rats. J. Clin. Invest. 94:663-671.

21. Wiener-Kronish, J.P., T. Sakuma, I. Kudoh, J.F. Pittet, D. Frank, L. Dobbs, M.L. Vasil, and M.A. Matthay. 1993. Alveolar epithelial injury and pleural empyema in acute $P$. aeruginosa pneumonia in anesthetized rabbits. $J$. Appl. Physiol. 75:1661-1669.

22. Smedira, N., L. Gates, R. Hastings, C. Jayr, T. Sakuma, J.F. Pittet, and M.A. Matthay. 1991. Alveolar and lung clearance in anesthetized rabbits. $J$. Appl. Physiol. 70:1827-1835.

23. Berthiaume, Y., V.C. Broaddus, M.A. Gropper, D. Tanita, and M.A. Matthay. 1988. Alveolar liquid and protein clearance from normal dog lungs. $J$. Appl. Physiol. 65:585-593.

24. Matthay, M.A., Y. Berthiaume, and N.C. Staub. 1985. Long-term clearance of liquid and protein from the lung of unanesthetized sheep. J. Appl. Physiol. 59:928-934.

25. Nelson, R.M., B.R. McIntyre, and E.A. Egan. 1978. Solute permeability of the alveolar epithelium in alloxan edema in dogs. J. Appl. Physiol. 44:353357.

26. Bland, J.M., and D.G. Altman. 1986. Statistical methods for assessing agreement between two methods of clinical measurement. Lancet. i:307-310.

27. Zar, J.H. 1984. Biostatistical Analysis. 2nd. ed. Prentice-Hall, Englewood Cliffs, NJ.

28. Yue, G., W.J. Russel, D.J. Benos, R.M. Jackson, M.A. Olman, and S. Matalon. 1995. Increased expression and activity of sodium channels in alveolar type II cells of hyperoxic rats. Proc. Natl. Acad. Sci. USA. 92:8418-8422.

29. Wiener-Kronish, J.P., V.C. Broaddus, K.H. Albertine, M. Gropper, M.A. Matthay, and N.C. Staub. 1988. Pleural effusions are associated with increased permeability pulmonary edema in anesthetized sheep. J. Clin. Invest. 82:1422-1429.

30. Bernard, G.R., A. Artigas, K.L. Brigham, J. Carlet, K. Falke, L. Hudson, L. Lamy, J.R. Legall, A. Morris, R. Spragg, and The Consensus Committee. 1994. The American-European Consensus Conference on ARDS. Am. J. Respir. Crit. Care Med. 149:818-824.

31. Terashima, T., H. Matsubara, M. Nakamura, F. Sakamaki, Y. Waki, K. Soejima, S. Tasaka, H. Nakamura, K. Sayama, A. Ishizaka, and M. Kanzawa. 1996. Local Pseudomonas instillation induces controlateral lung injury and plasma cytokines. Am. J. Respir. Crit. Care Med. 153:1600-1605.

32. Jayr, C., and M.A. Matthay. 1991. Alveolar and lung liquid clearance in the absence of pulmonary blood flow in sheep. J. Appl. Physiol. 71:1679-1687.

33. Garty, H., and D.J. Benos. 1988. Characteristics and regulatory mechanisms of the amiloride-blockade $\mathrm{Na}+$ channel. Physiol. Rev. 68:309-373.

34. O'Brodovitch, H., V. Hannam, and B. Rafii. 1995. Sodium channel but neither $\mathrm{Na}+\mathrm{H}+$ nor $\mathrm{Na}$-glucose symport inhibitors slow neonatal lung water clearance. Am. J. Respir. Cell Mol. Biol. 5:377-384.

35. Matalon, S. 1991. Mechanisms and regulation of ion transport in adult mammalian alveolar type II pneumocytes. Am. J. Physiol. (Lung Cell. Mol. Physiol.) 261:C727-C738.

36. Gatto, C., T.P. Green, M.G. Johnson, R.P. Marchessault, V. Seybold, and D.E. Johnson. 1987. Localization of quantitative changes in pulmonary beta-receptors in ovalbumin-sensitized guinea pigs. Am. Rev. Respir. Dis. 136: $150-154$.

37. Carstairs, J.R., A.J. Nimmo, and P.J. Barnes. 1985. Autoradiographic visualization of beta-adrenoceptor subtype in human lung. Am. Rev. Respir. Dis. 132:541-547.

38. Hamid, Q.A., J.C. Mak, M.N. Sheppard, B. Corrin, J.C. Venter, and P. Barnes. 1991. Localization of beta2-adrenoceptor messenger RNA in human lung and rat lung in situ hibridization: correlation with receptor autoradiography. Eur. J. Pharmacol. 206:133-138.

39. Mak, J.C.W., M. Nishikawa, and P.J. Barnes. 1994. Localization of betaadrenoceptor subtype mRNAs in human lung. Am. J. Respir. Crit. Care Med. 149(Suppl.):1027. 
40. Saumon, G., G. Basset, F. Bouchonnet, and C. Crone. 1987. cAMP and beta adrenergic stimulation of rat alveolar epithelium. Effects on fluid absorption and paracellular permeability. Pflueg. Arch. Eur. J. Physiol. 410:464-470.

41. Crandall, E.D., T.A. Heming, and B.E. Goodman. 1986. Effect of terbutaline on sodium transport in isolated perfused rat lung. J. Appl. Physiol. 60: 289-294.

42. Goodman, B.E., S.E.S. Brown, and E.D. Crandall. 1984. Regulation of transport across pulmonary alveolar epithelial cell monolayers. J. Appl. Physiol. 57:703-710.

43. Cott, G.R., K. Sugahara, and R.J. Mason. 1986. Stimulation net active ion transport across alveolar type II cell monolayer. Am. J. Physiol. (Lung Cell. Mol. Physiol.) 250:C222-C227.

44. Qi, M., Z.Z. Zhou, R.D. Wurster, and S.B. Jones. 1991. Mechanisms involved in the rapid dissipation of plasma epinephrine response to bacterial endotoxin in conscious rats. Am. J. Physiol. 261:R1431-R1437.

45. Michie, H.R., K.R. Manogue, and D.R. Spriggs. 1988. Detection of circulating tumor necrosis factor after endotoxin administration. N. Engl. J. Med. 318:1481-1486.

46. Hyers, T.M., S.M. Tricomi, P.A. Dettenmeyer, and A.A. Fowler. 1991. Tumor necrosis factor levels in serum and bronchoalveolar lavage fluid of patients with the adult respiratory distress syndrome. Am. Rev. Respir. Dis. 144: 268-271.

47. Suter, P.M., S. Suter, E. Girardin, P. Roux-Lombard, G.E. Grau, and J.M. Dayer. 1992. High bronchoalveolar levels of tumor necrosis factor and its inhibitors, interleukin-1, interferon and elastase, in patients with adult respiratory distress syndrome after trauma, shock, or sepsis. Am. Rev. Respir. Dis. 145: 1016-1022.

48. Stephens, K.E., A. Ishizaka, J.W. Larrick, and T. Raffin. 1988. Tumor necrosis factor causes increased pulmonary permeability and edema. Am. Rev. Respir. Dis. 137:1364-1370.

49. Tang, G., J.E. White, P.D. Lumb, D.A. Lawrence, and M.F. Tsan. 1995.
Role of endogenous cytokines in endotoxin- and interleukin-1-induced pulmonary inflammatory response and oxygen tolerance. Am. J. Respir. Cell Mol. Biol. 12:339-344.

50. Silva, A.T., and K.F. Bayston. 1990. Prophylactic and therapeutic effects of a monoclonal antibody to tumor necrosis factor-alpha in experimental gramnegative shock. J. Infect. Dis. 162:421-427.

51. Shall, T.J., M. Lewis, K.J. Koller, A. Lee, G.C. Rice, G.H.W. Wong, T. Gatanaga, A. Granger, R. Lentz, H. Raab, et al. 1990. Molecular cloning and expression of a receptor for human tumor necrosis factor. Cell. 61:361-370.

52. Shimomoto, H., Y. Hasegawa, Y. Nozaki, N. Takagi, T. Shibagaki, A. Nakao, and K. Shimokata. 1995. Expression of tumor necrosis factor receptors in human lung cancer cells and normal lung tissues. Am. J. Respir. Cell Mol. Biol. 13:271-278.

53. Nathan, C., and E. Sanchez. 1990. Tumor necrosis factor and CD11/ CD18 (beta 2) integrins act synergistically to lower cyclic AMP in human neutrophils. J. Cell Biol. 111:2171-2181.

54. Koga, S., S. Morris, S. Ogawa, H. Liao, J.P. Bilezikian, G. Chen, W.J. Thompson, T. Ashikaga, J. Brett, D.M. Stern, and D.J. Pinsky. 1995. TNF modulates endothelial properties by decreasing cAMP. Am. J. Physiol. 268:C1104C1113.

55. Brett, J., H. Gerlach, P. Nawroth, S. Steinberg, G. Godman, and D.M Stern. 1989. Tumor necrosis factor increases permeability of endothelial cell monolayers by a mechanism involving regulatory $\mathrm{G}$ proteins. J. Exp. Med. 169: 1977-1991.

56. MacGregor, G.G., R.E. Olver, and P.J. Kemp. 1994. Amiloride-sensitive $\mathrm{Na}+$ channels in fetal type II pneumocytes are regulated by $\mathrm{G}$ proteins. Am. J. Physiol. 267:L1-L8.

57. Baldwin, R.L., M.L. Stocowitz, L. Hood, and B.J. Wisnieski. 1996. Structural changes of tumor necrosis factor- $\alpha$ associated with membrane insertion and channel formation. Proc. Natl. Acad. Sci. USA. 93:1021-1026. 